\title{
The Relationship between Critical Thinking Ability of Iranian EFL Learners and Their Resilience Level Facing Unfamiliar Vocabulary Items in Reading
}

\author{
Zahra Kamali \\ College of Foreign Languages and Literature, Islamic Azad University, Science and Research Campus, Tehran, Iran \\ Email: manakamali@yahoo.com \\ Mansoor Fahim \\ College of Foreign Languages and Literature, Islamic Azad University, Science and Research Campus, Tehran, Iran \\ Email:dr.mfahim@yahoo.com
}

\begin{abstract}
In line with the studies in EFL/ESL contexts confirming the positive relationship between learner factors and language proficiency, this study investigated the relationship between critical thinking ability, resilience, and reading comprehension of texts containing unknown vocabulary items. For this purpose, 63 intermediate EFL learners were selected as the homogenized group. Afterwards, Peter Honey's (2004) appraisal test, Connor and Davidson's (2003) Resilience Scale, a vocabulary checklist, and a validated battery of four reading tests were given to the subjects. In order to empirically investigate the research hypotheses, the subjects were divided into two groups of high and low critical thinking and resilience groups. The results of the analyses for the collected data through t-test revealed that (a) the levels of critical thinking had significant effect on the scores of the subjects on resilience scale, (b) the levels of critical thinking had significant effect on the subjects' reading ability of texts with unfamiliar vocabulary items, and (c) the levels of resilience had significant effect on the subjects' reading ability of texts with unfamiliar vocabulary items. Therefore, the findings indicated that the three variables are related rejecting all three null hypotheses. The effect size index for the t-observed values were $.62, .79$, and .30, respectively. Moreover, the factor loadings for the four tests showed that the critical thinking questionnaire, resilience scale, and reading comprehension test all tap on the same underlying construct. The findings bear some implications for syllabus and materials designers, test developers, teachers and students' practice in EFL/ESL classrooms.
\end{abstract}

Index Terms — critical thinking ability, resilience, reading comprehension

\section{INTRODUCTION}

Educational psychology has for decades recognized, emphasized, and investigated the concept of individual learner differences; "it is undoubtedly true that learners bring many individual characteristics to the learning process which will affect both the way in which they learn and the outcomes of that process" (Williams \& Burden, 1997, p. 88). Recently, EFL/ESL researchers have focused their attention on the identification of such learner characteristics and investigation of their effects on the process, progress, and outcome of learning. One of the intellectual abilities which have been recognized as determiners of learning is critical thinking. As Freeley and Steinberg (2000) state critical thinking is "the ability to analyze, criticize, and advocate ideas; to reason inductively and deductively; and to reach factual or judgmental conclusions based on sound inferences drawn from unambiguous statements of knowledge or belief" (p. 2). Academically successful learners possess problem-solving, analytical, and critical thinking skills (De Boo, 1999; Gardner \& Jewler, 2000). Moreover, in dealing with stressful, challenging, and demanding world in which individuals (including L2 learners) live, the ability to overcome every day challenges and adverse situations is required to obtain academic and social success. Resilience, "a measure of successful stress-coping ability" (Connor \& Davidson, 2003, p.77), is a newly-developed psychological construct which can be considered as a personality factor of individual learners. It enables individuals to overcome difficult or traumatic circumstances and grow up to become healthy, educated, and successful citizens. Consequently, schools and communities, as Krovetz (2008) and Thomsen (2002) believe, need to build resilience in students, promoting their potential to succeed. However, the role of resilience in language achievement has not been investigated in the field of foreign and second language learning/ teaching. Therefore, one of the main purposes of the present study was to bring this construct into focus in L2 education and research, and explore the relationship of this personality factor of EFL/ESL learners with their cognitive ability of critical thinking. 
Given the tendency of language classrooms to promote debilitative anxiety (Horwitz et al., 1986, as cited in Finch, 2001), and the generally agreed upon proposition that learning a new language presents "a massive learning problem" (Stern, 1983, p. 381) demanding flexibility and higher-order thinking skills (Liaw, 2007), it seems inevitable for second language learners to be high critical thinkers and resilient individuals possessing personal resources and effective coping strategies which can contribute to their academic achievement. Moreover, since reading in a foreign language especially in the case of facing unfamiliar aspects of L2 can be anxiety-provoking to some learners (Saito, Garza, \& Horwitz, 1999), success of fluent and competent L2 readers in such challenging situations may be related to their level of critical thinking ability and resilience. Consequently, it is hoped that findings of the present study bring new correlates of success in reading comprehension of texts containing unknown vocabulary items.

It is vital for the future of a society that its children become competent and productive citizens. Therefore, a major focus in education and psychological literature, according to Melendez and Tomlinson-Clarke (2004), is the overall health and well-being of children and youth. As Masten and Coatsworth (1998) state research on competence provides a fundamental knowledge base for policies and programs that aim to promote successful development. In the educational system, there is an urgent need to understand the processes and factors that facilitate the development of competence. Critical thinking and reading ability may be of the protective factors competent individuals possess. The results of investigating the relationship between critical thinking, resilience and reading ability of EFL learners is expected to bring new insights into the identification of resources for healthy development and is, therefore, significant for designing competence-promoting programs at school, family, and community level.

\section{RESEARCH QUESTIONS AND HYPOTHESES}

For the above-stated purposes, the following research questions were raised:

1. Do learners' critical thinking levels have any significant effect on their scores on resilience scale?

2. Do learners' critical thinking levels have any significant effect on their reading ability of texts with unfamiliar vocabulary items?

3. Do learners' resilience levels have any significant effect on their reading ability of texts with unfamiliar vocabulary items?

Consequently, the following null hypotheses were also constructed:

Ho (1).Learners' critical thinking levels do not have any significant effect on their scores on resilience scale.

Ho (2).Learners' critical thinking levels do not have any significant effect on their reading ability of texts with unfamiliar vocabulary items.

Ho (3).Learners' resilience levels do not have any significant effect on their reading ability of texts with unfamiliar vocabulary items.

\section{MethodOLOGY}

\section{A. Participants}

A sample of 76 male and female students participated in this investigation. The subjects were intermediate EFL students learning English at Nourafshan English Language Institute in Karaj, Iran. Their age varied but all of them were adult EFL learners above 18. As the first step, these participants were given Nelson 200C English proficiency test in order to check their proficiency level and come up with the homogenized group. Through considering the normal distribution of the subjects' scores on proficiency test, the researcher chose those learners whose scores were one standard deviation above and one standard deviation below the mean. Consequently, 63 of them were found to be homogenous and were chosen for the purpose of the current study.

\section{B. Instruments}

For the purpose of the study, the following instruments were used:

a) A piloted version of Nelson 200C English proficiency test to determine the subjects' level of English language proficiency for the purpose of homogeneity. The test comprised of 40 multiple choice items which assessed the knowledge of English structures.

b) Peter Honey's (2004) 30- item critical thinking questionnaire adopted from Naieni (2005) to evaluate the skills of analysis, inference, evaluation, and reasoning. The reliability of the questionnaire was calculated amounting to .86 by Naieni (2005).

c) The 25-item Connor-Davidson (2003) Resilience Scale to measure subjects' stress-coping ability. The scale was developed as a brief self-rated assessment to help quantify resilience. It is made up of items reflecting several aspects of resilience including a sense of personal competence, tolerance of negative affect, positive acceptance of change, trust in one's instincts, sense of social support, spiritual faith, and an action-oriented approach to problem-solving. Initial work suggests that the scale is a promising measure for use with adult psychiatric and normal populations (Connor \& Davidson, 2003). The translation of the questionnaire into Persian and its adaptability into Iranian culture was done by Jokar, Samani, and Sahragard (2007). The reliability of the scale was calculated through Chronbach's $\alpha$ analysis amounting to .73 by Jokar, et al. (2007). 
d) A vocabulary checklist comprising of 216 words in order to enable the researcher to select reading passages with vocabulary items unknown to the subjects.

e) A battery of four reading passages selected from Advanced Reading Comprehension by Mirzaie (1991) in order to test subjects' reading comprehension ability of the texts including unfamiliar vocabulary items. To select appropriate passages for reading tests, two criteria were used. The first criterion was the judgment of the subjects' English language teacher who commented on the context and the content of the passages. The second criterion was the average readability of the passages in the students' textbook. In order to meet the final criterion, the readability of five passages selected from subjects' textbook was computed through Gunning Fog Index Readability Formula. The mean of the readability indexes of the passages were 10.11. The mean of the readability indexes of the selected passages for reading tests were 10.77 which was very near to the criterion mean.

\section{Procedure}

In order to test the research hypotheses of the study, the following steps were taken. First, to ensure the homogeneity of the participants, the piloted version of Nelson 200C English proficiency test was administered to 76 students. From among 76 learners who took part in the testing session, 63 learners whose scores were one standard deviation above and below the mean (scores between 16 and 22) were selected as the subjects of the present study. In the 4th session of the term, the subjects were provided with the Critical Thinking Questionnaire. In the next session, the subjects were given the Connor-Davidson Resilience Scale. To avoid any misunderstandings, the researcher used the translated versions of the two questionnaires. The translated version of the Critical Thinking Questionnaire and resilience scale were piloted by the researcher to 20 learners and the estimated reliability indices were .88 and .86 , respectively. Afterwards, to identify the unknown words for reading passages, a vocabulary checklist containing 216 vocabulary items was given to the subjects. After getting feedback from the subjects, four reading passages out of 10 reading passages were selected to test the reading comprehension ability of the sample when faced with unfamiliar vocabulary items. Each chosen test contained 10-15 unfamiliar vocabulary items and was followed by 5 multiple choice items.

\section{RESULTS}

\section{A. Testing the First Hypothesis}

In order to test the first hypothesis, i.e. learners' critical thinking levels do not have any significant effect on their scores on resilience scale, the students were divided into two groups of high and low critical thinking groups based on their median on critical thinking (CT), i.e. 107. In other words, the students whose scores on the CT were equal to or lower than 107 were considered as low critical thinking group and those with scorers higher than 107 consisted the high critical thinking group.

An independent t-test was run to compare the high and low critical thinking groups on the resilience scale. The tobserved value (see Table 1 ) is $5.53(p=.000<.05)$. Since the probability associated with the t-value is lower than the significance level of .05 , it can be claimed that there is a significant difference between the high and low critical thinking groups' mean scores on the resilience scale.

TABLE 1

INDEPENDENT T-TEST RESILIENCE SCALE BY CT LEVELS

\begin{tabular}{|c|c|c|c|c|c|c|c|c|c|}
\hline & \multicolumn{2}{|c|}{$\begin{array}{l}\text { Levene's Test for } \\
\text { Equality of Variances }\end{array}$} & \multicolumn{7}{|c|}{ t-test for Equality of Means } \\
\hline & \multirow[b]{2}{*}{$\mathrm{F}$} & \multirow[b]{2}{*}{ Sig. } & \multirow[b]{2}{*}{$\mathrm{t}$} & \multirow[b]{2}{*}{ Df } & \multirow{2}{*}{$\begin{array}{l}\text { Sig. }(2- \\
\text { tailed) }\end{array}$} & \multirow{2}{*}{$\begin{array}{l}\text { Mean } \\
\text { Difference }\end{array}$} & \multirow{2}{*}{$\begin{array}{l}\text { Std. Error } \\
\text { Difference }\end{array}$} & \multicolumn{2}{|c|}{$\begin{array}{l}\text { 95\% Confidence } \\
\text { Interval of the } \\
\text { Difference }\end{array}$} \\
\hline & & & & & & & & Lower & Upper \\
\hline $\begin{array}{l}\text { Equal variances } \\
\text { assumed }\end{array}$ & 10.588 & .002 & 5.487 & 61 & .000 & 20.665 & 3.766 & 13.134 & 28.197 \\
\hline $\begin{array}{l}\text { Equal variances not } \\
\text { assumed }\end{array}$ & & & 5.536 & 47.533 & .000 & 20.665 & 3.733 & 13.159 & 28.172 \\
\hline
\end{tabular}

Table 2 displays the descriptive statistics for the high and low CT groups on the resilience scale. The high CT group with a mean score of 73.29 outperformed the low CT group on the resilience scale.

TABLE 2

DESCRIPTIVE STATISTICS RESILIENCE SCALE BY CT LEVELS

\begin{tabular}{lllll}
\hline \hline CTLEVEL & $\mathrm{N}$ & Mean & Std. Deviation & Std. Error Mean \\
\hline HIGHCT & 31 & 73.29 & 9.873 & 1.773 \\
LOWCT & 32 & 52.62 & 18.580 & 3.284 \\
\hline
\end{tabular}


Based on these results, it can be concluded that the first null-hypothesis as learners' critical thinking levels do not have any significant effect on their scores on resilience scale is rejected. That is to say the levels of critical thinking have significant effects on the performance of the subjects on the resilience scale.

Based on the criteria developed by Cohen (1988, as cited in Cohen \& Brooke Lea, 2004), the independent t-test statistic is sensitive to number of sample and it only shows the statistical significance of the differences. The size of the difference - known as effect size - is much more important than its statistical significance. The effect size index criteria are:

.1 weak,

.3 medium and

.5 strong.

The effect size index for the $\mathrm{t}$-value of 5.53 is .62 which shows that the results of the independent $\mathrm{t}$-test are both statistically significant and important.

However, it should be noted that the two groups did not enjoy homogeneous variances (Levene' $\mathrm{F}=10.58 ; p=.002$ $<.05)$ (see Table 1). That is why the second row of Table 1 "Equal variances not assumed" is reported.

\section{B. Testing the Second Hypothesis}

In order to test the second hypothesis, i.e. learners' critical thinking levels do not have any significant effect on their reading ability of texts with unfamiliar vocabulary items, an independent t-test was run to compare the high and low critical thinking groups on their reading comprehension ability of texts with unfamiliar vocabulary items. The tobserved value, as shown in Table 3 , is $10.31(p=.000<.05)$. Since the probability associated with the t-value is lower than the significance level of .05 , it can be claimed that there is a significant difference between the high and low critical thinking groups' mean scores on the reading comprehension test.

TABLE 3

INDEPENDENT T-TEST READING COMPREHENSION BY CT LEVELS

\begin{tabular}{|c|c|c|c|c|c|c|c|c|c|}
\hline & \multicolumn{9}{|c|}{$\begin{array}{l}\text { Levene's Test for Equality of } \\
\text { Variances } \\
\text { t-test for Equality of Means }\end{array}$} \\
\hline & \multirow[b]{2}{*}{ F } & \multirow[b]{2}{*}{ Sig. } & \multirow[b]{2}{*}{$\mathrm{T}$} & \multirow[b]{2}{*}{ Df } & \multirow{2}{*}{$\begin{array}{l}\text { Sig. }(2- \\
\text { tailed) }\end{array}$} & \multirow{2}{*}{$\begin{array}{l}\text { Mean } \\
\text { Difference }\end{array}$} & \multirow{2}{*}{$\begin{array}{l}\text { Std. Error } \\
\text { Difference }\end{array}$} & \multicolumn{2}{|c|}{$\begin{array}{l}95 \% \text { Confidence Interval of } \\
\text { the Difference }\end{array}$} \\
\hline & & & & & & & & Lower & Upper \\
\hline $\begin{array}{l}\text { Equal variances } \\
\text { assumed }\end{array}$ & .002 & .966 & 10.313 & 61 & .000 & 4.707 & .456 & 3.794 & 5.619 \\
\hline $\begin{array}{l}\text { Equal variances not } \\
\text { assumed }\end{array}$ & & & 10.301 & 60.376 & .000 & 4.707 & .457 & 3.793 & 5.620 \\
\hline
\end{tabular}

Table 4 displays the descriptive statistics for the high and low CT groups' reading comprehension ability of texts containing unfamiliar vocabulary items. The high CT group with a mean score of 14.61 outperformed the low CT group on the reading comprehension test.

TABLE 4

DESCRIPTIVE STATISTICS READING COMPREHENSION BY CT LEVELS

\begin{tabular}{lllll}
\hline \hline CTLEVEL & $\mathrm{N}$ & Mean & Std. Deviation & Std. Error Mean \\
\hline HIGHCT & 31 & 14.61 & 1.874 & .337 \\
LOWCT & 32 & 9.91 & 1.748 & .309 \\
\hline
\end{tabular}

Based on these results, it can be concluded that the second null-hypothesis as learners' critical thinking levels do not have any significant effect on their reading ability of texts with unfamiliar vocabulary items is rejected. That is to say the levels of critical thinking have significant effects on the performance of the subjects on the reading comprehension test.

The effect size index for the t-value of 10.31 is .79 which shows that the results of the independent t-test are both statistically significant and important.

It should be noted that the two groups enjoy homogeneous variances (Levene' $\mathrm{F}=.002 ; p=.96>.05$ ) (see Table 3). That is why the first row of Table 3 "Equal variances assumed" is reported.

\section{Testing the Third Hypothesis}

In order to test the third hypothesis, i.e. learners' resilience levels do not have any significant effect on their reading ability of texts with unfamiliar vocabulary items, the students were divided into two groups of high and low resilience groups based on their median score of 67. In other words, the students whose scores on the resilience scale were equal to or lower than 67 were considered as low resilience group and those with scorers higher than 67 formed the high resilience group. 
An independent t-test was run to compare the high and low resilience groups on reading comprehension ability of texts with unfamiliar vocabulary items. The t-observed value, as shown in Table 5 , is $2.47(p=.016<.05)$. Since the probability associated with the t-value is lower than the significance level of .05 , it can be claimed that there is a significant difference between the high and low resilience groups' mean scores on the reading comprehension test.

TABLE 5

INDEPENDENT T-TEST READING COMPREHENSION BY RESILIENCE LEVELS

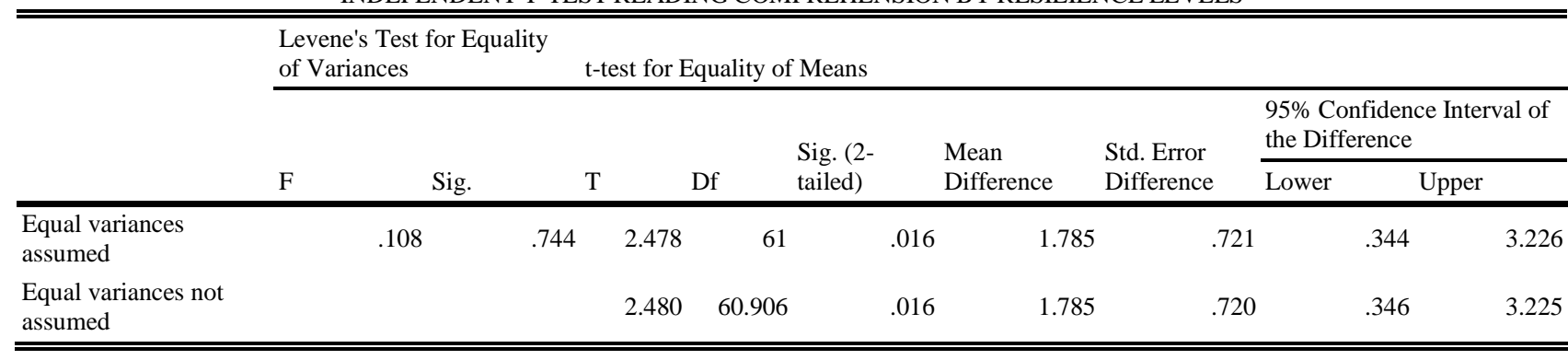

Table 6 displays the descriptive statistics for the high and low resilience groups' reading comprehension ability of texts with unfamiliar vocabulary items. The high resilience group with a mean score of 13.13 outperformed the low resilience group on the reading comprehension test.

TABLE 6

\begin{tabular}{lrcccc}
\multicolumn{2}{l}{ DESCRIPTIVE STATISTICS READING COMPREHENSION BY RESILIENCE LEVELS } \\
\hline \hline $\begin{array}{l}\text { Resilience } \\
\text { Scale }\end{array}$ & $\mathrm{N}$ & Mean & Std. Deviation & Std. Error Mean & \\
\hline & HIGH RES & 31 & 13.13 & 2.754 & .495 \\
& LOW RES & 32 & 11.34 & 2.958 & .523 \\
\hline
\end{tabular}

Based on these results, it can be concluded that the third null-hypothesis as learners' resilience levels do not have any significant effect on their reading ability of texts with unfamiliar vocabulary items is rejected. That is to say the levels of resilience have significant effects on the performance of the subjects on the reading comprehension test.

The effect size index for the t-value of 2.47 is .30 . That is to say although the results of the independent $t$-test are statistically significant, the effect size index of .30 shows that these results are of medium importance.

It should be noted that the two groups enjoy homogeneous variances (Levene' $\mathrm{F}=.10 ; p=.74>.05$ ) (see Table 5). That is why the first row of Table 5 "Equal variances assumed" is reported.

\section{Construct Validity of the Tests}

A factor analysis was run to probe the construct validity of the four tests administered in this study. The SPSS extracted two factors (see Table 7) which accounted for 81.92 percent of the total variance. This is a high index of construct validity for the battery of the tests employed in this study.

TABLE 7

TOTAL VARIANCE EXPLAINED

\begin{tabular}{|c|c|c|c|c|c|c|c|c|c|}
\hline \multirow[b]{2}{*}{ Component } & \multirow[b]{2}{*}{ Total } & \multicolumn{2}{|c|}{ Initial Eigenvalues } & \multicolumn{3}{|c|}{ Extraction Sums of Squared Loadings } & \multicolumn{3}{|c|}{ Rotation Sums of Squared Loadings } \\
\hline & & $\%$ of Variance & Cumulative $\%$ & Total & $\%$ of Variance & Cumulative $\%$ & Total & $\%$ of Variance & Cumulative \% \\
\hline 1 & 2.275 & 56.875 & 56.875 & 2.275 & 56.875 & 56.875 & 2.263 & 56.565 & 56.565 \\
\hline 2 & 1.002 & 25.049 & 81.923 & 1.002 & 25.049 & 81.923 & 1.014 & 25.359 & 81.923 \\
\hline 3 & .537 & 13.413 & 95.337 & & & & & & \\
\hline 4 & .187 & 4.663 & 100.000 & & & & & & \\
\hline
\end{tabular}

Table 8 displays the factor loadings for the four tests. The critical thinking, resilience, and reading comprehension tests all tap on the same underlying construct. That is to say, they seem to measure the same attribute. 
TABLE 8

FACTOR LOADINGS

\begin{tabular}{rrr}
\hline \hline & \multicolumn{2}{r}{ Component } \\
\cline { 2 - 3 } & \multicolumn{2}{c}{1} \\
\hline CT & .932 & \\
Resilience & .846 & \\
Reading & .823 & \\
Nelson & & .998 \\
\hline \hline
\end{tabular}

Due to the nature of the critical thinking, resilience, and reading comprehension tests and the high index of factor loading associated with critical thinking, the first factor may be labeled as critical thinking ability. As Seliger and Shohamy (1989) state, "those variables which have the highest loadings with the factors are used to define the factor" (p. 229). However, the Nelson test loads on a different factor that may be called, due to the nature of the Nelson test, as general proficiency factor.

\section{DISCUSSION}

Critical thinking is one of the cognitive abilities that "increase[s] the probability of a desirable outcome, ... the kind of thinking involved in solving problems, formulating inferences, calculating likelihoods, and making decisions" (Halpern, 2003, p.6). Today, it is strongly believed that higher-order thinking skills especially critical thinking should be an integral part of L2 curriculum to foster language proficiency of the EFL/ESL learners (Davidson, 1998; Chamot, 1995 as cited in Liaw, 2007). The findings of the present study seem to confirm and add to the literature in L2 learning concerning the important role of cognitive and personality factors in language learning.

The results indicated that EFL learners' critical thinking levels have significant effects on their resilience level. In other words, critical thinking as a cognitive ability and resilience as a personality factor are highly related. Reviewing the literature of resilience, the researcher noticed intellectual and cognitive abilities including planning ability, moral reasoning, problem solving skills, and intrapersonal reflective skills have been found by the researchers as the characteristics of resilient individuals, enabling them to succeed in life (Benard, 1998; Kumpfer, 1999; Brooks \&Goldstein, 2001; Melendez \& Tomlinson-Clarke, 2004). Emphasizing the link between problem-solving and decisionmaking skills and a resilient mindset, Brooks and Goldstein (2001) state:

When children can articulate problems, reflect on and engage in possible solutions, and consider other options if the initial solutions don't pan out, they demonstrate a resilient mindset. These skills foster a sense of ownership for and control of their own lives. (p. 228)

The results of examining the first hypothesis seem to provide empirical support for the prediction that critical thinking and resilience are related factors. However, since no studies, to the knowledge of the researcher, have investigated the relationship between critical thinking and resilience in the field of language teaching and learning, the results of testing the first hypothesis seems to bring a new construct and correlate of critical thinking ability into focus in the realm of TESOL which can ignite further research in the field of L2 education.

The study also revealed that learners' critical thinking levels have significant effects on their reading comprehension ability when faced with unknown vocabulary items. This finding aligns with Facione's (2007) finding that there is a significant correlation between critical thinking and reading comprehension; "improvements in the one are paralleled by improvements in the other" (p. 18). The presence of such a strong relationship may be due to the fact that critical thinking and reading are both cognitive abilities which have some identifiable cognitive skills in common. The cognitive skills of synthesis, evaluation, inference, and monitoring employed in the complex process of reading (Grabe, 1991, as cited in Celce-Murcia, 2001) are those cognitive skills that experts such as Facione (2007) consider as being at the very core of critical thinking: " as to the cognitive skills here is what the experts include as being at the very core of critical thinking: interpretation, analysis, evaluation, inference, explanation, and self-regulation" (p.4).

Although the researcher could not find a similar study carried out in Iran on the relationship between critical thinking and reading ability of texts containing unfamiliar vocabulary items, the results are particularly in line with three relevant studies. Saeepour (2009) carried out an investigation on the impact of teaching critical thinking skills on reading comprehension of Iranian EFL learners. The results of data analysis revealed that using critical thinking skills can help learners improve their reading comprehension as a general cognitive skill, and process information at deeper level. Sheikhy Behdani (2009) also conducted a research study on the relationship between autonomy, critical thinking ability, and reading comprehension of the Iranian EFL learners. The results showed that there existed a strong relationship between critical thinking ability of learners and their performance on reading comprehension. In other words, the higher the critical thinking ability, the higher the reading comprehension. In addition, critical thinking and autonomy of students were highly correlated. Finally, the relationship between critical thinking and lexical inferencing of EFL learners was examined by Mirzaie (2008). The researcher found out there was a relationship between critical thinking levels and lexical inferencing of learners. Confronted with unknown words while reading, those learners who had higher levels of critical thinking demonstrated more ability of lexical inferencing. The findings of the current study are 
consistent with the results of the above-stated investigations supporting the positive relationship between critical thinking ability and language learning especially the language skill of reading.

Furthermore, the analysis showed that levels of resilience have significant effects on the reading ability of the subjects when faced with unknown words. It should be noted that reading skill has been recognized by some experts as one of the characteristics of resilient individuals (Werner \& Smith, 1992, as cited in Jones, 2003; Kumpfer, 1999; Krovetz, 2008). Jones (2003) quotes Werner and Smith's (1992) finding that reading is a protective factor which helps individuals formulate their identity. It is an important developmental task for children and can lead to exhibiting qualities of resilience; "many resilient children and adolescents were competent readers" (p. 95). Additionally, Krovetz (2008) states effective reading skills by grade four (ages nine and ten) are one of the most potent predictors of successful adult adaptation. The results of the present study seem to provide confirmation of previous research findings concerning the positive relationship between resilience and reading skill. However, it should be stated that unlike the previous studies, the current study examined the relationship between resilience and second language reading skill. Therefore, before generalizing the result, the need is felt to conduct more research in the field of language teaching.

Not surprisingly, the prediction that resilient second language learners are more successful readers was confirmed through testing the third hypothesis suggesting that coming across unfamiliar aspects of L2, i.e. unknown words in a written text, can be an unfavorable condition that may create acute stress for low-resilient learners hindering the process of comprehension. An explanation for such a positive correlation between the two variables may lie in the shared attributes of skilled readers and resilient individuals. Flexibility, adaptability, and positive self-concept which characterize a resilient individual (Connor \& Davidson, 2003) have been identified by some authorities as the hallmarks of a good reader (Bowen et al., 1985; Nuttal, 1996; Grabe, 2002). "One of the principal characteristics of a good reader is flexibility... people who read flexibly are skilled at judging what they need to get out of a text to accomplish their purpose" (Nuttal, 1996, p.48). Grabe (2002) also believes the ability to flexibly and strategically adapt various processing and monitoring activities while reading marks a good reader. Finally, Bowen et al. (1985) mention unlike poor readers who have negative images, good readers enjoy positive self-concepts as readers.

In conclusion, the results revealed that there is a significant relationship between critical thinking ability, resilience, and reading comprehension suggesting that good internal resources such as high levels of critical thinking ability and resilience can affect academic performance, i.e. competence in reading, and may be considered as protective factors among $\mathrm{L} 2$ readers.

\section{PeDAgOGiCAl IMPliCATiOnS}

From the evidence of the study, some implications may be drawn. Since it has been found that levels of critical thinking have significant effects on both resilience and reading ability of texts with unknown words, it can be concluded that the utilization of critical thinking strategies would help learners read more effectively and improve their resilience and stress-management skills. Therefore, it is absolutely crucial for EFL/ESL teachers to encourage students to use their thinking abilities and provide them with challenging opportunities to reflect, grow, and learn. In other words, it is the responsibility of teachers to educate students for inquiry, problem solving, critical and creative thinking, and reflection which can contribute to their progress in language learning.

On the other hand, an awareness of learner characteristics and individual differences e.g., level of critical thinking ability and resilience can sensitize teachers to possible variations in learners' reactions to teaching and to differences in learning strategies, enabling them to make modifications, if necessary, to their approach to language teaching and adapt their teaching styles to learners' cognitive and personality variables.

Moreover, since the results showed that resilience is related to comprehension ability especially in the case of encountering unfamiliar words, it seems reasonable to suggest that fostering resilience of L2 readers may positively affect their reading performance particularly in dealing with such challenging and stress-provoking situations i.e., coming across unknown words. Consequently, EFL/ESL teachers should try to apply educational practices and strategies which help learners develop resilience particularly in coping with stressors and problems.

The prime suggestion would be directed for syllabus designers and materials developers. It seems that learners are very much in need of course books and materials that invoke critical thinking. Furthermore, the construct of resilience has not been receiving the attention it deserves in education including L2 education. Therefore, materials developers need to make an effort to create lessons that promote critical thinking and encourage students to reflect on their progress and take charge of their own thinking. They should also incorporate activities and practices which stimulate and build features of resilience, preparing them to function well in the society as competent and healthy citizens.

Finally, test developers should bring about changes in testing, constructing tests that integrate critical thinking skills and improve students' ability to think critically and reason effectively.

\section{REFERENCES}

[1] Benard, B. (1998). Fostering resiliency in kids: Protective factors in the family, school, and community. Retrieved March $5^{\text {th }}$, 2009, from University of Minnesota, National Resilience Resource Center website: http://www.cce.umn.edu/pdfs/NRRC/Fostering_Resilience_012804.pdf 
[2] Bowen, J. D., Madsen, H., \& Hilferty, A. (1985). TESOL techniques and procedures. Massachusetts: Newbury House Publishers, Inc.

[3] Brooks, R., \& Goldstein, S. (2001). Raising resilient children: Fostering strength, hope, and optimism in your child. Illinois: NTC/Contemporary Publishing Group, Inc.

[4] Celce-Murcia, M. (2001). Teaching English as a second or foreign language (3rd ed.). MA: Heinle \& Heinle.

[5] Cohen, B. H., \& Brooke Lea, R. (2004). Essentials of Statistics for the Social and Behavioral Sciences. Hoboken, NJ: John Wiley \& Sons, Inc.

[6] Connor, K. M., \& Davidson, J. R. T. (2003). Development of a new resilience scale: The Connor-Davidson resilience scale (CD-RISC). Depression and Anxiety, 18, 76-82.

[7] Davidson, B. W. (1998). Comments on Dwight Atkinson's "A Critical Approach to Critical Thinking in TESOL": A case for critical thinking in the English language classroom. TESOL Quarterly, 32(1), 119-123.

[8] De Boo, M. (1999). Enquiring children, challenging teaching. Buckingham: Open University Press.

[9] Facione, P. A. (2007). Critical thinking: What it is and why it counts. Retrieved February 22 ${ }^{\text {nd }}, 2009$, from http://insightassessment.com/t.html

[10] Finch, A. (2001). The non-threatening learning environment. The Korea TESOL Journal, 4(1), 133-158.

[11] Freely, A. J., \& Steinberg, D. L. (2000). Argumentation and debate: Critical thinking for reasoned decision-making. Stamford: Wadsworth.

[12] Gardner, J. N., \& Jewler, A. J. (2000). Your college experience: strategies for success (4th ed.). Belmont: Wadsworth.

[13] Grabe, W. (2002). Reading in a second language. In R. B. Kaplan (Ed.), The Oxford handbook of applied linguistics (pp. 4959). New York: Oxford University Press, Inc.

[14] Halpern, D. F. (2003). Thought and knowledge: An introduction to critical thinking (4th ed.). Mahwah, NJ: Lawrence Erlbaum Associates.

[15] Jokar, B., Samani, S., \& Sahragard, N. (2007). Resilience, psychological health, and life satisfaction. Journal of Psychiatric and Clinical Psychology of Iran, 50(3), 290-295.

[16] Jones, J. L. (2003). "I build resiliency": The role of the school media specialist. School Libraries Worldwide, 9 (2), $90-99$.

[17] Krovetz, M. L. (2008). Fostering resilience: Expecting all students to use their minds and hearts as well (2nd ed.). Thousand Oaks: Corwin Press.

[18] Kumpfer, K. L. (1999). Factors and processes contributing to resilience: The resilience framework. In M. D. Glantz \& J. L. Johnson (Eds.), Resilience and development: Positive life adaptations (pp. 179-224). New York: Kluwer Academic Publishers.

[19] Liaw, M. (2007). Content-based reading and writing for critical thinking skills in an EFL context. English Teaching and Learning, 31(2), 45-87.

[20] Masten, A. S., \& Coatsworth, J. D. (1998). The development of competence in favorable and unfavorable environments: Lessons from research on successful children. American Psychologist, 53(2), 205-220.

[21] Melendez, M. C., \& Tomlinson-Clarke, S. (2004). Home, school, and community: Catalysts to resilience. In C. S. ClaussEhlers \& M. D. Weist (Eds.), Community planning to foster resilience in children (pp. 311-325). New York: Kluwer Academic Publishers.

[22] Mirzaie, M. (1991). Advanced reading comprehension. Tehran: Ghazal Publications.

[23] Mirzaie, Z. (2008). The relationship between critical thinking and lexical inferences of Iranian EFL learners. Unpublished master's thesis, Islamic Azad University, Science and Research Campus, Tehran, Iran.

[24] Nuttall, C. (1996). Teaching reading skills in a foreign language. Oxford: Macmillan.

[25] Saeepour, M. (2009). The impact of teaching critical thinking skills on reading comprehension of Iranian EFL learners. Published master's thesis, Nonprofitable University of Khatam, Tehran, Iran.

[26] Saito, Y., Garza, T. J., \& Horwitz, E. K. (1999). Foreign language reading anxiety. The Modern Language Journal, 83(2), 202218.

[27] Seliger, H. W., \& Shohamy, E. (1989). Second language research methods. Hong Kong: Oxford University Press.

[28] Sheikhy Behdani, R. (2009). The relationship between autonomy, critical thinking ability, and reading comprehension of the Iranian EFL learners. Unpublished master's thesis, Islamic Azad University, Science and Research Campus, Tehran, Iran.

[29] Stern, H. H. (1983). Fundamental concepts of language teaching. Hong Kong: Oxford University Press.

[30] Thomsen, K. (2002). Building resilient students: Integrating resiliency into what you already know and do. Thousand Oaks: CA Corwin.

[31] Williams, M., \& Burden, R. L. (1997). Psychology for language teachers: A social constructivist approach. Cambridge: Cambridge University Press.

Zahra Kamali was born in Babol, Iran in 1984. She received her M. A. degree in teaching English as a foreign language from Islamic Azad University, Science and Research Branch, Iran in 2010.

Mansoor Fahim was born in Tehran, Iran. He received his PhD degree in teaching English as a foreign language. Dr. Fahim is currently a professor in Islamic Azad University, Science and Research Branch, Tehran, Iran. 